\title{
The Impact of Human Resource Management Practices and Leader Member Exchange on Job Performance: A moderating Role of Job Satisfaction in Jordanian Public Universities
}

\author{
A. M. Dirar', Rosima Alias' and M. Tamara ${ }^{2}$ \\ ${ }^{1}$ Faculty of Business Management and Accounting, University Tenaga National (Uniten) Malaysia; \\ derar_maaitah@yahoo.com,Rosima@uniten.edu.my \\ ${ }^{2}$ Faculty of Business Management, Northern Border University, Saudi Arabia Kingdom; Tamara_198992@yahoo.com
}

\begin{abstract}
Objectives: The purpose of the present study is to examine the relationship between Human resource practices, leader member exchange, job satisfaction and job performance in the public Jordanian universities, this study examine the moderating effects of job satisfaction on the relationship between human resource practices, leader member exchange and job performance. Methods/Statistical Analysis: The analysis was conducted using Structural Equation Model (SEM) to validate the research model and test the data. The final structural model that uses maximum likelihood estimation analysis confirmed goodness of fit to the data. Findings: The result of this study indicated that job satisfaction have significant(positive) moderating effect on the relationship between leader member exchange and job performance and insignificant (negative) moderating effect on the relationship between human resource practices and job performance. Improvements: This study contribute to the body of knowledge by providing empirical evidences to support theories and previous literature related to the moderating roles of job satisfaction in the relationship between human resource practices, leader member exchange and job performance. The present study concludes with research contributions and recommendations for further studies.
\end{abstract}

Keywords: Human Resource Practices, Leader Member Exchange, Job Performance, Job Satisfaction, Public Jordanian Universities

\section{Introduction}

In the Arab region, Jordan was once considered to be the top country in light of its educational system. However, in the educational context, Human Resource Management (HRM) dedicated studies in Jordan and the Arab countries are still few. In addition to this, the few existing studies are anecdotal rather than empirical and as such, the HRM practice in Jordanian firms cannot be enhanced if the practitioners remain in the dark concerning the nature of HRM current applications.

More importantly, HRM is significant to effective strategy implementation as evidenced in relevant litera- ture ${ }^{1}$. In other words, HRM is a prerequisite for successful organizations ${ }^{2}$.

And its practices provide employees with the required skills, incentives, information and facilitate decision making for the ultimate enhanced business performance ${ }^{3}$. In this globalized era, organizations are faced with the challenge of balancing between local and global markets in terms of the design and implementation of HRM practices and as such, this has become a critical issue for different firms (multinational and domestic) 4 .

It is crucial for practitioners to ensure consistency between HR business strategies and plans through adap-

${ }^{*}$ Author for correspondence 
tation ${ }^{5}$. Hence, the overall HRM themes are combined in its entire functions, while making sure that they adhere to the goals of the organization ${ }^{4}$. Several studies have delved into the primary competitive business factors in light of their contribution to the economies of countries. According to ${ }^{1}$, the attempt to acquire has been the core to the strategic management field and within such field; the configuration theory has arisen as a resolution to a new framework that analyzes competitive advantage in terms of its sources and sustainability. In this background, HRM studies are divided into two streams, namely internal and external fit. The scholars are of the consensus that along with the internal organization characteristics, the characteristics of the environment also influence the performance of firms as they primarily reflect the demands among customers. Leader Member Exchange has significant developed in the past 30 years from role and social theories is the Leader-Member Exchange (LMX) theory. It lays stress on the supervisors-subordinates relationship. Prior work on the topic like ${ }^{6}$ evidenced a positive LMX-subordinate performance outcomes relationship, organizational commitment as well as job satisfaction. They stated that past studies examined the effect of supervisor behavior and transformational leadership on the performance of followers. Past studies on the subject has also indicated that all subordinates are not treated equally by their supervisor and as such, the latter creates groups (in-group and out-group) ${ }^{z}$. More importantly, studies focused on the human resource management practices and the interaction between leaders and members on job performance has yet to be extensively examined. Therefore, the present study empirically investigates the effect of human resource management practices, and leader-member interaction on job performance among the public universities in Jordan. The findings are expected to assist in making wise decisions and enhance the public universities conditions in the same context.

\section{Literature Survey}

According to ${ }^{\underline{8}}$ study concerned global competition as a fundamental element for determining firm's strategies, as a result of which, industrial economy has shifted towards knowledge economy. The author stated that in the present dynamic business environment, organizations are faced with increasing challenges of attaining and optimizing sustainable competitive advantages (HRM) ${ }^{2}$. Total quality is of primary significance in the present age, where effi- ciency can only be realized through the successful human resource use, in a way that human resource management has become of the pre-requisites of business success. The HRM department has a key role in providing human resources to companies in light of recruitment, orientation and performance appraisal. According to ${ }^{9}$ functions of HRM have arisen as one of the most significant ones in organizations practices.

Human resource practices is a process that assists in the effective performance of HR functions like providing actual and timely information regarding the recruitment process, which eventually saves company costs. Management requires planning and management when it comes to compensating employees. HR planning is geared towards linking enlightening employees with the vision, needs and strategic plans of the organization and the entire human resources aspects 2 .

An effective HR planning makes sure that the most suitable employees are appropriated the right positions in the organization the processes of human resource guarantees that the employees of the organization have the required skills and competencies that the firm can leverage for successful goal achievement ${ }^{9}$. Another HR practices in any business firm, both recruitment and selection play a key role in human resource management and they refer to the process of attracting and choosing employee candidates. HR quality of the firm largely depends on the two functions effectiveness ${ }^{10}$. Performance appraisal refers to a significant practice used to measure the employees' effectiveness and efficiency ${ }^{11}$ and it consists of four phases namely, technical, extended, appraisal and maintenance ${ }^{12}$. In relation to this, performance management practices consist of future development plans that provide managers training, measure the performance appraisals quality, resolves ineffective performance, and establishes consistency and feedback throughout the organization. The last one of HR practices in this study is compensation; Performance-based compensation is the top HR practice that stresses on rewarding employees because of their initiatives ${ }^{10}$. Aside from performance-based compensation, $\underline{\underline{13}}$ also referred to merit compensation as rewards (monetary or non-monetary) that are provided to employees in exchange for their service in terms of their efforts, contributions and performance.

The LMX quality is often determined at the earlier stages of the relationship development between the leader and the members and the relationship has a tendency to become stable as time passes, enabling LMX to be a 
good predictor of performance, results and attitudes of members. Specifically, LMX of high quality is related with enhanced followers' performance ${ }^{6}$, and employees who maintain such high quality LMX have a higher inclination to work overtime and to take a step further in work accomplishments. However, this does not mean that LMX do not lead to negative outcomes, in fact, owing to the differences in the subordinates' treatment, unfairness can arise among the groups creating in-group and out-group ${ }^{8}$. LMX have four diminutions (Affect, Loyalty, Contribution, and Professional Respect) all these diminution enhance the job performance for the organizations. Job satisfaction refers to the job in terms of affective, cognitive and behavioral elements of different aspects including pay, promotion, work tasks, colleagues, and supervisors, among others ${ }^{\underline{14}}$. It is the employees' attitudes and feelings concerning their job and the level to which they have positive emotions towards the job role ${ }^{15}$. Other studies defined it as the psy- chological state of the way individual perceives his work - his feelings and attitudes concerning different elements (intrinsic and extrinsic) towards his job and the organization ${ }^{13}$. Several researchers have viewed it as an invaluable construct in examining employee attitudes and behaviors. On the other hand, lack of job satisfaction may lead to low level of productivity and high level of absenteeism, accidents at work, and issues concerning mental and physical health ${ }^{3}$. Additionally, high job satisfaction levels enhance productivity, while low levels minimize productivity and performance as evidenced in ${ }^{5}$.

\section{Methodology}

In the quantitative research, population denotes the entire collection of people, events, or things that the study needs to explore. As confirmed before, this research focuses on the public Jordanian universities. According to the sta-

Table 1. Distribution of public universities in Jordan Region

\begin{tabular}{|l|l|l|}
\hline Region & University & $\begin{array}{l}\text { Total number of } \\
\text { academic staffs }\end{array}$ \\
\hline South & Mu’tah University & 572 \\
& Al-Hussein bin Talal University & 275 \\
& Tafila Technical University & 214 \\
\hline \multirow{2}{*}{ Middle } & The University of Jordan & 1312 \\
& The Hashemite University & 687 \\
& Al-Balqa Applied University & 1077 \\
& German Jordanian University & 271 \\
\hline \multirow{2}{*}{ North } & Yarmouk University & 1083 \\
& Jordan University of Science and Technology & 1005 \\
& Al al-Bayt University & \\
\hline
\end{tabular}

Source Ministry of Higher Education (2017)

Table 2. Examining Results of Hypothesized Direct Effects of the Variables

\begin{tabular}{|l|l|l|l|l|l|l|}
\hline \multicolumn{2}{|l|}{ Unstandardized Estimate } & $\begin{array}{l}\text { Standardised } \\
\text { Estimate }\end{array}$ & \multicolumn{2}{l|}{$\begin{array}{l}\text { critical ration } \\
\text { (c.r.) }\end{array}$} & P-value & $\begin{array}{l}\text { Hypothesis } \\
\text { Result }\end{array}$ \\
\hline \multicolumn{2}{|l|}{ Estimate } & & \multicolumn{2}{l|}{ S.E. } & Beta & \\
\hline HP - JBP & 0.174 & 0.083 & $0.148^{*}$ & 2.11 & 0.035 & Supported \\
\hline RS - JBP & 0.137 & 0.064 & $0.128^{*}$ & 2.124 & 0.034 & Supported \\
\hline PA - JBP & 0.132 & 0.063 & $0.12^{*}$ & 2.08 & 0.038 & Supported \\
\hline CM - JBP & 0.154 & 0.076 & $0.136^{*}$ & 2.016 & 0.044 & Supported \\
\hline AF - JBP & 0.011 & 0.087 & 0.008 & 0.128 & 0.898 & Rejected \\
\hline LY - JBP & 0.158 & 0.075 & $0.143^{*}$ & 2.096 & 0.036 & Supported \\
\hline CN - JBP & 0.171 & 0.069 & $0.153^{*}$ & 2.489 & 0.013 & Supported \\
\hline PR - JBP & 0.171 & 0.077 & $0.141^{*}$ & 2.215 & 0.027 & Supported \\
\hline
\end{tabular}

Source (this research) 
tistics published via the ministry of higher education in Jordan (2017) (Table 1), there were 10 public universities with a total number of 6863 academic staffs holding master degree and Ph.D. for the intention of managing this research, each university having a number of greater than 100 of academic staff were involved to obtain portion in this research (Table 2).

So, the academic staffs have been chosen from 10 public universities which are located in Amman and other main cities of Jordan, hence, the population of this research is the whole number of academic staff in 10 public Jordanian universities $(\mathrm{N}=6863)$ ministry of higher education in Jordan (2017) .

Seven paths are displayed from HR planning, requirement and selection, performance appraisal, compensation, loyalty, contribution and professional respect to job performance - and they are all statistically significant, as evidenced by their p-values that remained below the standard significance level of 0.05 . In contrast, the path of affect to job performance was not statistically significant, more importantly the most significant job performance predictor in structural model 2 is contribution as evidenced by a standardized path coefficient amounting to 0.153 .

The next sub-sections provide detailed discussions on the path analysis outcomes relating to the above mentioned hypotheses in the second structural model.

\section{Conclusion}

The study examined the HRM, LMX and job performance relationship, with the moderating role of job satisfaction. Questionnaire copies were distributed to 346 academic staff in Jordanian public universities and SEM was used for assessment and testing of hypotheses. According to the results obtained, HRP, LMX, and job satisfaction improve the job performance of staff working in public Jordanian universities. The findings of this study support the moderating role of job satisfaction on the HRP-job performance and LMX-job performance relationship in Jordanian public universities. This could be used as a stepping stone to further avenues of research by future authors. Empirical work can include additional constructs that can act as a moderating variable like organizational justice and organizational citizenship behavior. Future research may also conduct a study including private universities. Additionally, future stud- ies can use this study's framework on other countries that have similar working environments in light of similar variables. Future studies can adopt first-order constructs and examine it through SEM. Study replications can focus on the dimensions of variables that may reveal in-depth results of the constructs' relationships. Majority of studies have supported the importance of LMX in prior decades, reporting its positive and negative aspects. One of such negative aspects is the quantitative measure it utilized. Future studies using LMX can use a qualitative method instead as suggested $\frac{16,17}{}$.

For instance, semi-structured interviews can provide insight into LMX and its effect on the performance, motivation and attitudes of members. The supervisors can be focused on as the focal point rather than the members to obtain the perceptions of both parties.

Finally, qualitative methods can be used by future studies on government organizations as such studies are still scarce. Consequently, state government organizations may be examined to obtain information of LMX impact on the employee and agencies working within.

This research has several recommendations According to the research findings, several recommendations are brought forward for the stakeholders. The first recommendation is provided to the ministry, which lays stress on the retention of top talent - which is the major issue in firms and institutions in the present times. Such entities look into investing on workers to retain them, motivate them and ultimately, ensure sustainability of business, and enhance competitiveness. The findings of this study are expected to lay stress on the motivation of workers and the significance of LMX.

As to the management of universities, an employment policy may boost job security of staff - in other words, it is crucial to invest in human resources and IS to enhance staff effectiveness, ensure their recruitment and selection on the basis of equal employment opportunity premise.

In this regard, public universities are recommended to develop new systems to enhance HRP, in terms of training, performance appraisal, team work and compensation to bring about higher staff job satisfaction. Management can make use of LMX to heighten the level of job satisfaction and job performance among academic staff in Jordanian public universities as their performance directly relates to the learning quality and successful graduates. The benefits of recruitment and selection of employees can be reaped through employee satisfaction, which should be a main priority in organizations. 
Following the adoption of HRP, new employees have to be appraised and inculcated with new trends and challenges, and in doing so, the organization can be sustained through the satisfaction of employees. According to the findings, employee rewards are pertinent in increasing satisfaction and performance. Thus, pay and benefits should be used to motivate employee commitment along with the provision of praises and recognition.

Lastly, greater LMX level indicates that subordinates would be recipients of different advantages (formal and informal rewards) that lead to ease in accessing supervisors and opportunities growth. It is recommended that the Ministry of Higher Education and Scientific Research in Jordan promote and recognize the number of years of service and aspirations of academic staff to realize improved staff satisfaction, and in turn, improve their job performance.

\section{References}

1. Abdullah AB, Wan HL. Relationships of non-monetary incentives, job Satisfaction and employee job performance. International Review of Management and Business Research. 2013; 2(4):1085-91.

2. Ahmed RU. A comparative research on job satisfaction and HRM practices: Empirical investigation of few commercial bank employees in Bangladesh. International Journal of Human Resource Studies. 2015; 5(2):290-300. https://doi. org/10.5296/ijhrs.v5i2.7765

3. Bos-Nehles A, Bondarouk T, Nijenhuis K. Innovative work behaviour in knowledge-intensive public sector organizations: The case of supervisors in the Netherlands fire services. The International Journal of Human Resource Management. 2017; 28(2):379-98. https://doi.org/10.1080 /09585192.2016.1244894

4. Saridakis G, Lai Y, Cooper CL. Exploring the relationship between HRM and firm performance: A meta analysis of longitudinal studies. Human Resource Management Review. 2016; 27(1):87-96. https://doi.org/10.1016/j.hrmr.2016.09.005

5. Shmailan AW, Baig A. Amelioration in Retailing in India and GCC Region. Industrial Engineering Letters. 2015; $5(1): 1-6$.

6. Jha S, Jha S. Leader-member exchange: A critique of theory and practice. Journal of Management and Public Policy. 2013; 4(2):42-53.
7. Chen Y, Yu E, Son J. Beyond Leader-Member Exchange (LMX) differentiation: An indigenous approach to leadermember relationship differentiation. The Leadership Quarterly. 2014; 25(3):611-27. https://doi.org/10.1016/j. leaqua.2013.12.004

8. Aggarwal A, Thakur GSM. Techniques of performance appraisal-a Review. International Journal of Engineering and Advanced Technology. 2013; 2(3):617-21.

9. Examining the relationship between strategic HRM and hospital employees' work attitudes: An analysis across occupational groups in public and private hospitals [Internet]. [cited 2016 Nov 10]. Available from: https://www.tandfonline.com/doi/abs/10.1080/09585192.2016.1254104.

10. Valarmathi MJ, Babu RR. Human resource management practices in selected private sector banks in Puducherry. A special reference to work life balance of women employees. International Journal ofAdvanced Scientific Research and Development. 2015; 2(2):118-25.

11. Ali SB, Mahdi A, Malihe J. The Effect of Employees' Performance Appraisal Procedure on their Intrinsic Motivation. International Journal of Academic Research in Business and Social Sciences. 2012, 2 (12):161-168.

12. People management in the public sector. file://C:/Users/a/ Downloads/9783319575827-c2.pdf. Date accessed: 2018.

13. Stress and turnover intents in international organizations: Social support and work-life balance as resources [Internet]. Available from: https://www.tandfonline.com/ doi/abs/10.1080/09585192.2016.1254105.

14. The Palgrave handbook of public administration and management in Europe [Internet]. [cited 2018]. Available from: https://www.palgrave.com/in/book/9781137552686.

15. Saboor A, Mukhtar M, Sadiq MK. LMX as a Predictor of Performance Behaviour: Empirical Evidence from Life Insurance Sector of Pakistan. Journal of Human Resource Management. 2015; 3(1):1-5. https://doi.org/10.11648/j. jhrm.20150301.11

16. Contextualizing performance appraisal practices in Chinese public sector organizations: The importance of context and areas for future study [Internet]. [cited 2017 Feb 20]. Available from: https://www.tandfonline.com/doi/ abs/10.1080/09585192.2017.1292537?journalCode=rijh20.

17. The Management of People in Mission-Driven Organizations [Internet]. [cited 2017 Oct 12]. Available from: https://link. springer.com/chapter/10.1007/978-3-319-57583-4_1. 